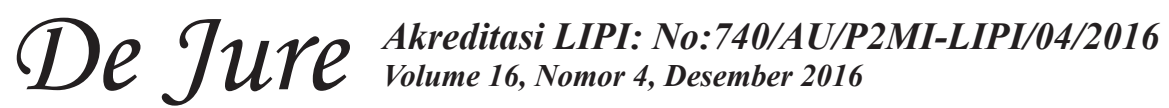

Jurnal Penelitian Hukum De Jure adalah majalah hukum triwulan (Maret, Juni, September dan Desember) diterbitkan oleh Badan Penelitian dan Pengembangan Hukum dan HAM Kementerian Hukum dan HAM RI bekerjasama dengan IKATAN PENELITI HUKUM INDONESIA (IPHI) Pengesahan Badan Hukum Perkumpulan Keputusan Menteri Hukum dan Hak Asasi Manusia Nomor : AHU-13.AHA.01.07 Tahun 2013, Tanggal 28 Januari 2013, bertujuan sebagai wadah dan media komunikasi, serta sarana untuk mempublikasikan aneka permasalahan hukum yang aktual dan terkini bagi para peneliti hukum Indonesia khususnya dan kalangan masyarakat pemerhati hukum pada umumnya.

Penanggung Jawab

Y. Ambeg Paramarta, S.H.,M.Si

(Kepala Badan Penelitian dan Pengembangan Hukum dan Hak Asasi Manusia)

\section{Pemimpin Umum}

Marulak Pardede, S.H.,M.H.,APU

(Ketua Ikatan Peneliti Hukum Indonesia)

\section{Wakil Pemimpin Umum}

T. Daniel L. Tobing, S.H

(Kepala Pusat Pengembangan Data dan Informasi Peneliti Hukum dan Hak Asasi Manusia)

DR. Agus Anwar, S.H.,M.H

(Kepala Pusat Penelitian dan Pengembangan Hukum)

Pemimpin Redaksi

Akhyar Ari Gayo, S.H.,M.H.,APU (Hukum Islam, BALITBANGKUMHAM)

\section{Anggota DewanRedaksi}

DR. Ahmad Ubbe, S.H.,M.H., APU (Hukum Adat, BALITBANGKUMHAM)

Mosgan Situmorang, S.H.,M.H (Hukum Perdata, BALITBANGKUMHAM)

Syprianus Aristieus, S.H.,M.H (Hukum Perusahaan, BALITBANGKUMHAM)

Nevey Varida Ariani, S.H.,M.H (Hukum Pidana, BALITBANGKUMHAM)

Eko Noer Kristiyanto, S.H (Hukum Perdata, BALITBANGKUMHAM)

Muhaimin, S.H (Hukum Islam, BALITBANGKUMHAM)

\section{Redaksi Pelaksana}

Yatun, S.Sos

Sekretaris

M. Virsyah Jayadilaga, S.Si.,M.P

Asmadi

\section{Tata Usaha}

Dra. Evi Djuniarti, M.H

Galuh Hadiningrum, S.H

Suwartono 


\section{TUTe $\begin{aligned} & \text { Akreditasi LIPI: No:740/AU/P2MI-LIPI/04/2016 } \\ & \text { Volume 16, Nomor 4, Desember } 2016\end{aligned}$}

Teknologi Informasi dan Desain Layout

Risma Sari, S.Kom., M.Si (Teknologi Informasi)

Machyudhie, S.T (Teknologi Infornasi)

Saefullah, S.ST.,M.Si (Teknplogi Informasi)

Agus Priyatna, S.Kom (Desain Layout)

Teddy Suryotejo

\section{Mitra Bestari}

Prof. DR. Rianto Adi, M.A (Sosilogi Hukum, UNIKA ATMAJAYA JAKARTA)

Prof. DR. Jeane Neltje Saly, S.H.,M.H (Hukum Humaniter, UNIV. 17 Agustus 1945 Jakarta)

Prof. DR. Hibnu Nugroho, S.H (Hukum Fidana, FH. UNSOED)

DR. Farhana, S.H.,M.H (Hukum Pidana, Fak. Hukum Universitas Islam Jakarta)

DR. Ridwan Nurdin, M.A (Hukum Syariah, Fakultas Syariah Univ. Arraniri Banda Aceh)

DR. Hadi Supratikta (Administrasi Pemerintahan, Balitbang Kemendagri)

\section{Alamat Redaksi:}

Gedung Badan Penelitian dan Pengembangan Hukum dan Hak Asasi Manusia

Kementerian Hukum dan Hak Asasi Manusia Republik Indonesia

Jl. HR. Rasuna Said Kav.4-5, Kuningan, Jakarta Selatan

Telepon, (021)2525015, Faksimili (021) 2526438

Email :

jurnaldejure@yahoo.com

balitbangkumham@gmail.com

ejournaldejure@gmail.com

\section{Percetakan}

PT Pohon Cahaya

Jalan Gedung Baru 18 Jakarta Barat 11440

Telpon (021) 5600111, Faksimili (021) 5670340

Redaksi menerima naskah karya asli yang aktual dalam bidang hukum berupa hasil penelitian dari berbagai kalangan, seperti: peneliti hukum, praktisi dan teoritisi, serta berbagai kalangan lainnya. Tulisan-tulisan yang dimuat merupakan pendapat pribadi penulisnya, bukan pendapat redaksi.

Redaksi berhak menolak, menyingkat naskah tulisan sepanjang tidak mengubah isinya. Naskah tulisan dapat dikirim ke alamat redaksi, maksimum 30 halaman A4, diketik spasi dua rangkap dikirim melalui Email: jurnaldejure@yahoo.com atau melalui aplikasi Open Journal System (OJS) pada URL/website: ejournalbalitbangham.go.id 


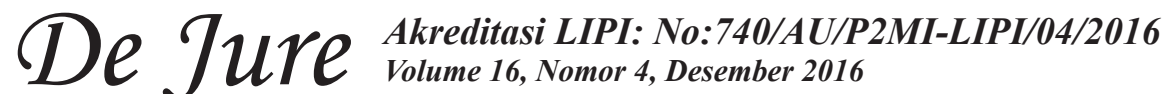

\section{DAFTAR ISI}

Halaman

\section{DAFTAR ISI}

ADVERTORIAL

Peningkatan Akses Bantuan Hukum Kepada Masyarakat Miskin

(Intensif Access of Law aids to the Poor)

$463-475$

Oki Wahju Budijanto

DAFTAR RIWAYAT HIDUP

505 - 506

PEDOMAN PENULISAN

$507-508$ 


\section{De TuPe $\begin{aligned} & \text { Akreditasi LIPI: No:740/AU/P2MI-LIPI/04/2016 } \\ & \text { Volume 16, Nomor 4, Desember } 2016\end{aligned}$}

Puji syukur kehadirat Allah SWT, Jurnal Penelitian Hukum De Jure yang diterbitkan Badan Penelitian dan Pengembangan Hukum dan HAM Kementerian Hukum dan Hak Asasi Manusia bekerjasama dengan Ikatan Peneliti Hukum Indonesia dapat menerbitkan Volume 16 Nomor 4, Desember 2016.

Para pembaca Jurnal Penelitian Hukum De Jure yang tercinta, sebagaimana diketahui bahwa pada tanggal 10 Desember setiap tahunnya diperingati sebagai Hari Hak Asasi Manusia sedunia. Tanggal ini dipilih untuk menghormat Majelis Umum PBB yang mengadopsi dan memproklamirkan Deklarasi Universal Hak Asasi Manusia, sebuah pernyataan global tentang hak asasi manusia pada 10 Desember 1948.

Apabila menilik Hukum dan HAM, merupakan konsepsi kemanusiaan dan relasi sosial yang dilahirkan dari sejarah peradaban manusia di seluruh penjuru dunia. Hukum dan HAM juga dapat dimaknai sebagai hasil perjuangan manusia untuk mempertahankan dan mencapai harkat kemanusiaannya. Agar HAM dapat ditegakkan dalam berbagai kehidupan harus ada instrumen yang mengaturnya. Instrumen tersebut berisi aturanaturan bagaimana HAM itu ditegakkan dan mengikat seluruh warganegara. Sebagai negara yang menjunjung tinggi HAM Indonesia telah memiliki setidak-tidaknya empat instrumen HAM, yakni UUD 1945, TAP MPR Nomor XVII/MPR/1998, UU Nomor 39 Tahun 1999 tentang Hak Asasi Manusia.

Dari beberapa intrumen yang ada tersebut berharap perlindungan dan penegakan HAM kedepanya dapat meningkat, karena masih banyak kekurangan-kekurangan yang harus diperbaiki oleh pemerintah. Seperti lebih difungsikan secara maksimal lembaga-lembaga yang memiliki tugas khusus menegakan HAM.

Dalam rangka memperingati Hari Hak Asasi Manusia Sedunia tersebut, Dewan Redaksi mengangkat tuisan-tulisan dari para peneliti di lingkungan Kementerian Hukum dan HAM yang bersinggungan dengan penegakan Hukum dan HAM di Indonesia.

Akhirnya kami menyampaikan ucapan terima kasih kepada Kepala Badan Penelitian dan Pengembangan Hukum dan HAM Kementerian Hukum dan HAM RI dan Ketua Ikatan Peneliti Hukum Indonesia dalam penerbitan buku ini. Dan juga kami ucapkan terima kasih kepada Prof. DR. Rianto Adi, M.A., Prof. DR. Jeane Neltje Saly, S.H.,M.H., Prof. DR. Hibnu Nugroho, S.H., DR. Farhana, S.H., M.H., DR. Ridwan Nurdin, M.A.,dan DR. Hadi Supratikta, Selaku Mitra Bestari yang telah bersedia membantu memeriksa dan mengoreksi tulisan dari para penulils.

Jakarta, Desember 2016 


\title{
PENINGKATAN AKSES BANTUAN HUKUM KEPADA MASYARAKAT MISKIN (Intensify Access of Law Aids To the Poor)
}

\author{
Oki Wahju Budijanto \\ Peneliti pada Pusat Pengembangan Data dan Informasi Penelitian Hukum \\ dan Hak Asasi Manusia, Badan Penelitian dan Pengembangan Hukum dan Hak Asasi Manusia \\ Kementerian Hukum dan Hak Asasi Manusia Republik Indonesia \\ Jalan HR Rasuna Said Kavling 4 -5, Jakarta Selatan 12920 \\ Telepon (021)2525015 Faksimili (021)2526438 \\ HP: 08158113742 - E-mail: oki_olive@yahoo.com \\ Tulisan Diterima: 9-11-2016; Direvisi: 25-11-2016; \\ Disetujui Diterbitkan: 23-12-2016
}

\begin{abstract}
Law aids access have experienced some problems/obstacles such as: regulation, officers professionalism, and society understanding in accessing of law aids. Therefore, the problem is how to increase law aids access to the poor. The expected benefits of this writing is recommendation to the Minister of Law and Human Rights to make policy formulation related to law aids program. It is a qualitative method by two techniques in collecting data with descriptive approach. To enhance the law aids to the poor so this writing generates some recommendation : need more coordination by means of DILKUMJAKPOL forum in adjusting understanding about law aids implementation; require a review related to financial fund in law aids, proportionally by considering necessity each area; necessary to broaden socialization area to villages/ urban communities; it is necessary to do data collection of poor inmates so it can be used by the National Law Development Agency as legal aids administrator; need to revise the Ministerial Regulation of Law and Human Rights of R.I. Number 3 Year 2013 concerning Procedures for Verification and Accreditation of Law Aids Institution or A Certain Social Organization article 12 letter e and $f$.
\end{abstract}

Keywords: access, law aids, the poor

\begin{abstract}
ABSTRAK
Akses bantuan hukum mengalami berbagai permasalahan/kendala antara lain: kendala regulasi, profesionalisme aparat, dan pemahaman masyarakat dalam mengakses bantuan hukum. Oleh karena itu, permasalahan yang muncul adalah bagaimana meningkatkan akses bantuan hukum kepada masyarakat miskin? Tujuan tulisan ini adalah untuk meningkatkanakses bantuan hukum kepada masyarakat miskin. Manfaat yang diharapkan adalah sebagai bahan rekomendasi kepada Kementerian Hukum dan HAM dalam membuat rumusan kebijakan yang berkaitan dengan program bantuan hukum. Tulisan ini menggunakan metode kualitatif dengan dua teknik pengumpulan data melalui pendekatan deskriptif. Dalam upaya meningkatkan akses pemberian bantuan hukum bagi masyarakat miskin, maka studi ini mengajukan beberapa rekomendasi: perlu meningkatan koordinasi melalui forum DILKUMJAKPOL dalam menyeleraskan pemahaman tentang implementasi bantuan hukum; perlu meninjau kembali penerapan besaran dana bantuan hukum dengan mempertimbangkan besaran dana secara proporsional sesuai dengan kebutuhan masing-masing daerah; perlu memperluas jangkauan sosialisasi hingga ke tingkat desa/kelurahan; perlu melakukan pendataan tahanan miskin agar data tersebut dapat digunakan secara langsung oleh BPHN sebagai penyelenggara bantuan hukum. perlu merevisi Peraturan Menteri Hukum dan Hak Asasi Manusia Republik Indonesia Nomor 3 Tahun 2013 tentang Tata Cara Verifikasi Dan Akreditasi Lembaga Bantuan Hukum Atau Organisasi Kemasyarakatan khusus Pasal 12 huruf e dan f.
\end{abstract}

Kata Kunci: Akses, Bantuan Hukum, Masyarakat Miskin 


\section{PENDAHULUAN}

Pemberian bantuan hukum adalah salah satu perwujudan dari amanat Pasal 28D ayat (1) Undang-Undang Dasar Negara Republik Indonesia Tahun 1945 Amandemen Kedua yang menyatakan "Setiap orang berhak atas pengakuan, jaminan, perlindungan, dan kepastian hukumyang adil serta perlakuan yang sama dihadapan hukum". UndangUndang Dasar Negara Republik Indonesia Tahun 1945 mengualifikasikan hak atas pengakuan, jaminan, perlindungan, dan kepastian hukum yang adil serta perlakuan yang sama di hadapan hukum sebagai bagian dari hak asasi manusia.

Jimly Asshiddiqie (2007) Penyebutan hak dalam Undang-Undang Dasar Negara Republik Indonesia Tahun 1945 membawa konsekuensi tertentu, baik terhadap pengualifikasiannya maupun pihak mana yang memiliki kewajiban utama dalam pemenuhannya. Oleh karena disebutkan secara resmi dalam konstitusi, maka hak tersebut dikualifikasi sebagai hak konstitusional setiap warga negara. Dengan demikian, negara adalah pemegang kewajiban utama dalam pemenuhannya.

Pelaksanaan bantuan hukum di Indonesia saat ini diatur dalam Undang-Undang Republik Indonesia Nomor 16 Tahun 2011 tentang Bantuan Hukum. Selanjutnya, penerima bantuan hukum berdasarkan undang-undang tersebut hanyalah terbatas pada orang atau kelompok orang miskin saja. Berita LBH Jakarta (2013: 20) UndangUndang Bantuan Hukum merupakan upaya yang ditempuh negara untuk menjamin hak konstitusional warga negara untuk mendapatkan akses keadilan dan kesamaan di hadapan hukum. Pembentuk undang-undang juga menyadari bahwa pelaksanaan hak konstitusional warga negara selama ini belum berjalan secara baik. Keberadaan Undang-Undang Bantuan Hukum sebagai sesuatu yang wajar dan sudah selayaknya dilakukan oleh pemerintah.Undang-Undang ini juga dapat dimaknai sebagai penanda adanya 'lembaran baru' perjuangan masyarakat miskin untuk mendapatkan hak-hak mereka.

Sudaryono (2012: 220) menyatakan bantuan hukum merupakan hal yang sangat esensial dalam menciptakan kehidupan yang adil serta melindungi hak asasi manusia dimana bantuan hukum yang diberikan bertujuan untuk melindungi hak asasi manusia dalam hal masalah hukum guna menghindari segala macam tindakan yang dapat membahayakan atau tindakan sewenang-wenang aparat penegak hukum atau aparat pemerintahan.

Frans H Winarta (2011: 79) menyatakan Lembaga Bantuan Hukum (LBH) sebagai salah satu subsistem dari system peradilan pidana (criminal justice system) dapat memegang peranan penting dalam membela dan melindungi hak-hak tersangka.

Selanjutnya, untuk melaksanakan ketentuan Pasal 15 ayat (5) dan Pasal 18 Undang-Undang Republik Indonesia Nomor 16 Tahun 2011 maka Pemerintah menerbitkan Peraturan Pemerintah Republik Indonesia Nomor 42 Tahun 2013 tentang Syarat dan Tata Cara Pemberian Bantuan Hukum dan Penyaluran Dana Bantuan Hukum. Kemudian, untuk melaksanakan peraturan pemerintah diatas maka pemerintah dalam hal ini Kementerian Hukum dan HAM RI menerbitkan Peraturan Menteri Hukum dan Hak Asasi Manusia Republik Indonesia Nomor 22 Tahun 2013 tentang Peraturan Pelaksanaan Peraturan Pemerintah Nomor 42 Tahun 2013 tentang Syarat dan Tata Cara Pemberian Bantuan Hukum dan Penyaluran Dana Bantuan Hukum, yang kemudian diganti dengan Peraturan Menteri Hukum dan Hak Asasi Manusia Republik Indonesia Nomor 10 Tahun 2015 tentang Peraturan Pelaksanaan Peraturan Pemerintah Nomor 42 Tahun 2013 tentang Syarat dan Tata Cara Pemberian Bantuan Hukum dan Penyaluran Dana Bantuan Hukum.

Selanjutnya, untuk melaksanakan ketentuan Pasal 7 ayat (4) Undang-Undang Nomor 16 Tahun 2011 tentang Bantuan Hukum, maka telah ditetapkan Peraturan Menteri Hukum dan Hak Asasi Manusia Republik Indonesia Nomor 3 Tahun 2013 tentang Tata Cara Verifikasi dan Akreditasi Lembaga Bantuan Hukum Atau Organisasi Kemasyarakatan.

Implementasi pemberian bantuan hukum mengalami berbagai permasalahan/kendala antara lain: kendala regulasi, profesionalisme aparat, dan pemahaman masyarakat dalam mengakses bantuan hukum. Selain itu, implementasi bantuan hukum juga dipengaruhi sistem bantuan hukum yang ada sebelum Undang-Undang Bantuan Hukum diterapkan. Permasalahan untuk mendapatkan keadilan meskipun terbatas pada bantuan hukum, sebenarnya adalah masalah yang tidak mudah diuraikan. Hal ini karena masalah akses mendapatkan keadilan bukan hanya masalah 


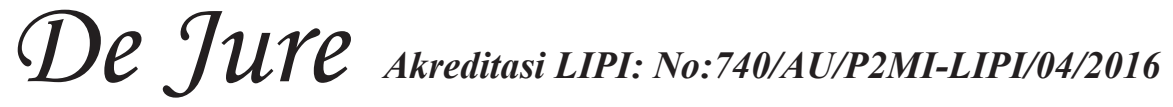

hukum semata melainkan juga masalah politik, bahkan lebih jauh lagi adalah masalah budaya.

Dalam upaya pemanfaatan hasil penelitian, studi ini berupaya melakukan systematic review terhadappenelitian-penelitian dengantemabantuan hukum. Adapun penelitian terkait dengan bantuan hukum yang telah dilakukan dan digunakan untuk kepentingan studi ini adalah sebagai berikut :

1. Peran Pemerintah Daerah Dalam Pemenuhan Hak Atas Keadilan (Badan Penelitian dan Pengembangan HAM tahun 2012).

2. Hak atas Layanan Bantuan Hukum Bagi Masyarakat Miskin (Badan Penelitian dan Pengembangan HAM tahun 2015).

3. Bantuan Hukum Masih Sulit Diakses Hasil Pemantauan di Lima Provinsi (Nusa Tenggara Timur, Nusa Tenggara Barat, Sulawesi Selatan, Sumatera Utara dan DKI Jakarta) Terkait Pelaksanaan Undang-Undang Nomor 16 Tahun 2011 tentang Bantuan Hukum (Kontras tahun 2014)

4. Implementasi Bantuan Hukum Pada Masyarakat Miskin di Kota Bandar Lampung (Andan Adi Satriawan, Upik Hamidah SH. MH dan Satria Prayoga SH. MH Jurnal Universitas Lampung tahun 2014).

Kesimpulan umum yang dapat ditarik dari keempat penelitian di atas adalah:

1. Pola pemberian bantuan hukum yaitu pemberian bantuan hukum non litigasi, litigasi dan gabungan non litigasi dan litigasi.

2. Potensi penerima bantuan hukum jumlahnya sangat besar, namun sistem bantuan hukum yang dijalankan saat ini belum sesuai dengan kebutuhan riil terhadap bantuan hukum.

3. Keberadaan progam bantuan hukum yang merupakan implementasi Undang-Undang Bantuan Hukum belum sepenuhnya dipahami oleh aparat penegak hukum.

4. Pemenuhan persyaratan administrasi bantuan hukum menyulitkan Organisasi Bantuan Hukum (OBH), sehingga menimbulkan keengganan $\mathrm{OBH}$ untuk mengikuti program tersebut.

5. Akses terhadap program bantuan hukum bagi masyarakat masih terbatas terutama karena minimnya jumlah $\mathrm{OBH}$.

6. Masyarakat pada umumnya tidak mengetahui adanya hak atas bantuan hukum gratis Hal ini karena minimnya akses masyarakat miskin terhadap informasi terkait program bantuan hukum gratis.

Berdasarkan kesimpulan penelitianpenelitian sebelumnya, maka permasalahan yang muncul adalah bagaimana meningkatkan akses bantuan hukum kepada masyarakat miskin? Peningkatan akses bantuan hukum dilihat pada tataran normatif, kelembagaan dan administrasi yang mampu menjawab permasalahan tersebut.

Berdasarkan permasalahan di atas, maka tujuan dari studi ini adalah untuk mengetahui peningkatan akses bantuan hukum kepada masyarakat miskin. Sedangkan manfaat yang diharapkan dari penelitian ini adalah sebagai bahan rekomendasi kepada Kementerian Hukum dan HAM dalam membuat rumusan kebijakan yang berkaitan dengan program bantuan hukum.

\section{METODE PENELITIAN}

Pengumpulan data dilakukan melalui dua tahap yaitu: penelitian kepustakaan untuk memperoleh data sekunder melalui penelusuran kepustakaan baik buku-buku hasil penelitian maupun jurnal, serta akses internet

Penelitian lapangan dilakukan dengan cara mengumpulkan para pemangku kepentingan melalui Focus Group Discussion (FGD) dan pemilihan lokasi pelaksanaan FGD secara random, yaitu: Provinsi Jawa Timur; Provinsi Aceh; Provinsi Sumatera Selatan; dan Provinsi Kalimantan Selatan.

. Irwanto (2006:1-2) menerangkan FGD atau diskusi terarah merupakan suatu diskusi yang dilakukan secara sistematis mengenai suatu permasalahan tertentu yang sangat spesifik melalui diskusi kelompok.

Data yang terkumpul baik dari hasil penelitian lapangan maupun dari penelitian kepustkaan dianalisis dengan menggunakan metode kualitatif deangan pendekatan desktiptif.

\section{PEMBAHASAN}

\section{A. Organisasi Bantuan Hukum}

Indonesia sebagai negara yang menganut paham negara hukum berdasarkan Pasal 1 ayat (3) Undang-Undang Dasar Negara Republik Indonesia Tahun 1945, harus menjunjung tinggi 
hak asasi manusia dalam segala bentuk. Bentuk perlindungan terhadap hak asasi manusia, diantaranya adalah dengan memberi jaminan dan perlindungan agar setiap orang memiliki kedudukan yang sama dihadapan hukum dengan tidak ada pengecualiannya.

Pengaturan lebih lanjut mengenai hak setiap orang juga telah diatur didalam Undang-Undang Republik Indonesia Nomor 39 Tahun 1999 tentang Hak Asasi Manusia mengenai hak-hak dasar yang harus dihormati. Seperti yang kita ketahui, hak asasi manusia merupakan seperangkat hak yang melekat pada hakikat dan keberadaan manusia sebagai makhluk Tuhan Yang Maha Esa dan merupakan anugerah-Nya yang wajib dihormati, dijunjung tinggi dan dilindungi olehnegara, hukum, pemerintah, dan setiap orang demi kehormatan serta perlindungan harkat dan martabat manusia itu sendiri. Berdasarkan hal tersebut, maka negara menjamin hak dasar setiap orang.

Pelaksanaan bantuan hukum di Indonesia saat ini telah diatur di dalam Undang-Undang Republik Indonesia Nomor 16 Tahun 2011 tentang Bantuan Hukum. Selanjutnya, penerima bantuan hukum berdasarkan undang-undang tersebut hanyalah terbatas pada orang atau kelompok orang miskin saja. Padahal menurut Undang-Undang Dasar Negara Republik Indonesia Tahun 1945 Pasal 27 ayat (1) "Segala warga negara bersamaan kedudukannya di dalam hukum dan pemerintahan dan wajib menjunjung hukum dan pemerintahan itu dengan tidak ada kecualinya" dan Pasal 28D ayat (1) "Setiap orang berhak atas pengakuan, jaminan, perlindungan dan kepastian hukum yang adil serta perlakuan yang sama dihadapan hukum".

Berdasarkan Pasal 1 angka 3 UndangUndang Nomor 16 Tahun 2011 tentang Bantuan Hukum:Pemberi bantuan hukum adalah lembaga bantuan hukum atau organisasi kemasyarakatan yang memberi layanan bantuan hukum berdasarkan Undang-Undang Bantuan Hukum.

Syarat-syarat pemberi bantuan hukum meliputi:
a) Berbadan hukum;
b) Terakreditasi berdasarkan Undang-Undang Bantuan Hukum;
c) Memiliki kantor atau sekretariat yang tetap;
d) Memiliki pengurus; dan
e) Memiliki program bantuan hukum.

Pasal 9 Undang-Undang Bantuan Hukum memberikan hak kepada pemberi bantuan hukum untuk:

a) Melakukan rekrutmen terhadap advokat, paralegal, dosen, dan mahasiswa fakultas hukum;

b) Melakukan pelayanan bantuan hukum;

c) Menyelenggarakan penyuluhan hukum, konsultasi hukum, dan program kegiatan lain yang berkaitan dengan penyelenggaraan bantuan hukum;

d) Menerima anggaran dari negara untuk melaksanakan bantuan hukum berdasarkan Undang-Undang Bantuan Hukum;

e) Mengeluarkan pendapat atau pernyataan dalam membela perkara yang menjadi tanggung jawabnya di dalam sidang pengadilan sesuai dengan ketentuan peraturan perundang-undangan;

f) Mendapatkan informasi dan data lain dari pemerintah ataupun instansi lain, untuk kepentingan pembelaan perkara; dan

g) Mendapatkan jaminan perlindungan hukum, keamanan, dan keselamatan selama menjalankan pemberian bantuan hukum.

Sementara itu, pemberi bantuan hukum diberikan kewajiban untuk:

a) Melaporkan kepada menteri tentang program bantuan hukum;

b) Melaporkan setiap penggunaan anggaran negara yang digunakan untuk pemberian bantuan hukum berdasarkan Undang-Undang Bantuan Hukum;

c) Menyelenggarakan pendidikan dan pelatihan bantuan hukum bagi advokat, paralegal, dosen, mahasiswa fakultas hukum yang direkrut;

d) Menjaga kerahasiaan data, informasi, dan/ atau keterangan yang diperoleh dari penerima bantuan hukum berkaitan dengan perkara yang sedang ditangani, kecuali ditentukan lain oleh undang-undang; dan

e) Memberikan bantuan hukum kepada penerima bantuan hukum berdasarkan syarat dan tata cara yang ditentukan dalam UndangUndang Bantuan Hukum sampai perkaranya selesai, kecuali ada alasan yang sah secara hukum. 


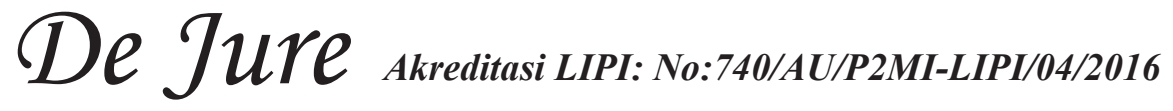

Dalam memahami ketentuan undang-undang bantuan hukum tentang pemberi bantuan hukum meliputi: lembaga bantuan hukum dan organisasi kemasyarakatan yang dalam aktivitasnya melakukan bantuan hukum. Selanjutnya dalam studi ini digunakan istilah Organisasi Bantuan Hukum (OBH) yang merujuk pada kedua bentuk organisasi pemberi bantuan hukum.

Pasal 11 Undang-Undang Bantuan Hukum memberi hak imunitas kepada pemberi bantuan hukum, dimana pemberi bantuan hukum tidak dapat dituntut secara perdata atau pidana dalam memberikan bantuan hukum yang menjadi tanggung jawabnya yang dilakukan dengan itikad baik di dalam maupun di luar sidang pengadilan sesuai standar bantuan hukum berdasarkan peraturan perundang-undangan dan/atau kode etik advokat. Hak imunitas tersebut bukan tanpa batas. Pemberi bantuan hukum dilarang menerima atau meminta pembayaran dari penerima bantuan hukum dan/atau pihak lain yang terkait dengan perkara yang sedang ditanganinya.

Peraturan untuk melaksanakan UndangUndang Bantuan Hukum tersebut, Pemerintah telah menerbitkan Peraturan Pemerintah Republik Indonesia Nomor 42 Tahun 2013 tentang Syarat dan Tata Cara Pemberian Bantuan Hukum dan Penyaluran Dana Bantuan Hukum serta Peraturan Menteri Hukum dan Hak Asasi Manusia Republik Indonesia Nomor 22 Tahun 2013 tentang Peraturan Pelaksanaan Peraturan Pemerintah Nomor 42 Tahun 2013 tentang Syarat dan Tata Cara Pemberian Bantuan Hukum dan Penyaluran Dana Bantuan Hukum yang kemudian diganti dengan Peraturan Menteri Hukum dan Hak Asasi Manusia Republik Indonesia Nomor 10 Tahun 2015 tentang Peraturan Pelaksanaan Peraturan Pemerintah Nomor 42 Tahun 2013 tentang Syarat dan Tata Cara Pemberian Bantuan Hukum dan Penyaluran Dana Bantuan Hukum.

Sementara itu, untuk melaksanakan ketentuan Pasal 7 ayat (4) Undang-Undang Nomor 16 Tahun 2011 tentang Bantuan Hukum, maka telah ditetapkan Peraturan Menteri Hukum dan Hak Asasi Manusia Republik Indonesia Nomor 3 Tahun 2013 tentang Tata Cara Verifikasi Dan Akreditasi Lembaga Bantuan Hukum Atau Organisasi Kemasyarakatan. Pasal 12 Peraturan Menteri Hukum dan HAM Republik Indonesia Nomor 3 Tahun 2013 menetapkan bahwa: Lembaga bantuan hukum atau organisasi yang mengajukan permohonan verifikasi dan akreditasi sebagai pemberi bantuan hukum harus memenuhi syarat:

a) Berbadan hukum;

b) Memiliki kantor atau sekretariat yang tetap;

c) Memiliki pengurus;

d) Memiliki program bantuan hukum;

e) Memiliki advokat yang terdaftar pada lembaga bantuan hukum atau organisasi; dan

f) Telah menangani paling sedikit 10 (sepuluh) kasus.

Penelitian yang dilakukan oleh Badan Penelitian dan Pengembangan HAM pada tahun 2012 dengan judul Peran Pemerintah Daerah Dalam Pemenuhan Hak Atas Keadilan (Studi Tentang Akses Bantuan Hukum Bagi Masyarakat Miskin) dengan pembahasan meliputi : model pelaksanaan bantuan hukum "probono" serta peran pemerintah daerah, penegak hukum, lembaga advokat dan perguruan tinggi dalam pelaksanaan bantuan hukum "probono". Pada tahun 2015 Badan Penelitian dan Pengembangan HAM juga telah melakukan penelitian tentang "Hak atas Layanan Bantuan Hukum Bagi Masyarakat Miskin" dengan pembahasan meliputi : kondisi pemenuhan hak masyarakat miskin untuk mendapatkan layanan bantuan hukum serta faktor-faktor yang mempengaruhi pemenuhan hak masyarakat miskin untuk mendapatkan akses bantuan hukum.

Kesimpulan yang dapat ditarik dari kedua penelitian di Badan Penelitian dan Pengembangan HAM mengenai bantuan hukum adalah:

1. Tiga pola dalam pemberian bantuan hukum yaitu pemberian bantuan hukum non litigasi, litigasi dan gabungan non litigasi dan litigasi;

2. Pemerintah daerah dan pengadilan kurang menginformasikan tentang bantuan hukum;

3. Akses masyarakat terhadap bantuan hukum relatif masih terbatas karena minimnya keberadaan $\mathrm{OBH}$;

4. Undang-Undang Bantuan Hukum belum sepenuhnya dipahami oleh aparat penegak hukum;

5. Sistem bantuan hukum masih dirasakan berbelit-belit. 
Kontras pada tahun 2014 melakukan penelitian dengan judul Bantuan Hukum Masih Sulit Diakses Hasil Pemantauan di Lima Provinsi (Nusa Tenggara Timur, Nusa Tenggara Barat, Sulawesi Selatan, Sumatera Utara dan DKI Jakarta) Terkait Pelaksanaan Undang-Undang Nomor 16 Tahun 2011 tentang Bantuan Hukum. Hasil penelitian tersebut menyimpulkan bahwa akses terhadap program bantuan hukum bagi masyarakat masih terbatas terutama karena minimnya keberadaan organisasi pemberi bantuan hukum atau akses wilayah yang sulit dicapai secara geografis. Di sisi lain, fasilitasi dalam bentuk dukungan dana bagi organisasi bantuan hukum ini juga menyimpan persoalan bagi efektivitas pelaksanaan bantuan hukum mengingat perbandingan dukungan dana dengan kebutuhan dalam pemberian bantuan hukum yang tidak sebanding. Selain ketidakcukupannya dalam memenuhi kebutuhan pemberian bantuan hukum, pendanaan ini juga tidak dapat memberikan kontribusi bagi keberlanjutan organisasi pemberi bantuan hukum, terutama bagi organisasi yang mandiri atau tidak terafiliasi dengan organisasi lainnya. Pengembangan layanan bantuan hukum juga menjadi program kerja di beberapa pemerintah daerah. Inisiatif ini perlu direspon oleh pemerintah untuk mengefektifkan pemberian layanan bantuan hukum dan memperluas akses masyarakat untuk mendapatkan bantuan hukum.

Jurnal terbitan tahun 2014 dari Universitas Lampung dengan penulisnya: Andan Adi Satriawan, Upik Hamidah SH. MH dan Satria Prayoga SH. MH. dengan judul Implementasi Bantuan Hukum Pada Masyarakat Miskin di Kota Bandar Lampung (Studi di Lembaga Bantuan Hukum Bandar Lampung). Pembahasan dalam jurnal ini meliputi implementasi bantuan hukum pada masyarakat miskin di Kota Bandar Lampung serta faktor-faktor penghambat implementasi bantuan hukum pada masyarakat miskin di Kota Bandar Lampung.

Kesimpulan dari jurnal bantuan hukum tersebut adalah:

1. Masih minimnya payung hukum untuk masalah bantuan hukum khususnya dalam hal anggaran pemberian bantuan hukum.

2. Jumlah dari petugas atau pemberi bantuan hukum masih sangat sedikit.

3. Kurangnya pengetahuan masyarakat tentang bantuan hukum.
Secara normatif, merujuk dari keempat hasil penelitian di atas bahwa baik peraturan perundang-undangan maupun aturan pelaksana telah mengatur mengenai program bantuan hukum kepada masyarakat miskin, namun dalam pelaksanaannya dinilai belum optimal.

Hal yang menarik dari keempat penelitian tersebut bahwa secara umum disimpulkan bahwa minimnya akses bantuan hukum kepada masyarakat miskin dikarenakan minimnya jumlah $\mathrm{OBH}$.

\section{B. Akses Bantuan Hukum}

Undang-Undang Nomor 16 Tahun 2011 tentang BantuanHukum(Undang-Undang Bantuan Hukum) memberi peluang terhadap perlindungan hak warga negara yang sedang menjalani proses hukum. Ada dua latar belakang yang menjadi dasar pembentukan Undang-Undang Bantuan Hukum, yaitu (i) jaminan negara terhadap hak konstitusional setiap orang untuk mendapatkan pengakuan, jaminan, perlindungan dan kepastian hukum yang adil serta perlakuan yang sama di hadapan hukum sebagai sarana perlindungan HAM, (ii) negara bertanggung jawab terhadap pemberian bantuan hukum bagi orang miskin sebagai perwujudan akses terhadap keadilan.

Secara garis besar, tujuan bantuan hukum yang tercantum dalam Pasal 3 Undang-Undang Bantuan Hukum tersebut adalah mewujudkan akses kepada keadilan bagi masyarakat miskin dan juga mewujudkan peradilan yang efektif, efisien, dan dapat dipertanggungjawabkan (akuntabel). Jadi bantuan hukum tidak semata untuk memberikan jasa hukum bagi masyarakat akan tetapi sekaligus diharapkan mampu mendorong perbaikan sistem peradilan. Bantuan hukum diharapkan mampu menjadi sistem yang membantu melindungi hak masyarakat dalam proses hukum untuk memperoleh keadilan melalui sistem peradilan transparan dengan menerapkan prinsip perlindungan Hak Asasi Manusia (HAM).

Disamping itu, pemberian bantuan hukum bagi masyarakat miskin tidak serta merta hanya ditujukan kepada pemerintah pusat, akan tetapi juga ditujukan kepada pemerintah daerah. Hal tersebut tertuang di dalam Undang-Undang Republik Indonesia Nomor 16 Tahun 2011 Pasal 3 poin c yang menyatakan "menjamin kepastian penyelenggaraan Bantuan hukum dilaksanakan secara merata di seluruh wilayah Negara Republik Indonesia". Berdasarkan undang-undang tersebut, 


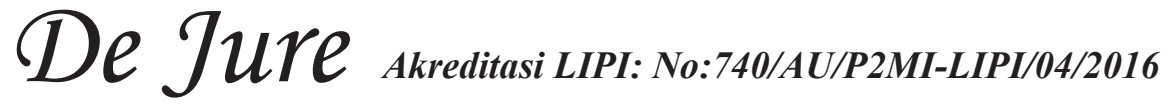

memberikan kesempatan bagi pemerintah daerah dalam mendukung program bantuan hukum di daerah masing-masing. Dukungan yang dimaksud berbentuk alokasi penyelenggaraan bantuan hukum di dalam APBD yang diatur kemudian di dalam peraturan daerah masing-masing (Pasal 19 Undang-Undang Nomor 16 Tahun 2011). Dengan tercantumnya pasal ini, penyelenggaraan bantuan hukum seharusnya mendapatkan dukungan yang lebih banyak, karena baik pemerintah pusat dan pemerintah daerah dapat menyediakan dana untuk membantu organisasi bantuan hukum di seluruh wilayah Indonesia.

Julius Ibrani, YLBHI (2013) menyatakan untuk mengisi ruang kosong dan lebih menyempurnakan program bantuan hukum dapat juga disiasati dengan pembentukan peraturan daerah tentang bantuan hukum di tingkat provinsi.

Selanjutnya untuk bisa menilai kualitas praktek dari sistem bantuan hukum, UNDP (2012:8) memberikan beberapa indikator yang bisa dijadikan pedoman penilaian, yaitu:

1. Akses masyarakat terhadap bantuan hukum primer (accessibility of primary legal aid to the population)

Layanan bantuan hukum tentu harus bisa diakses oleh masyarakat yang membutuhkan. Lembaga pemberi bantuan hukum harus bisa menjangkau seluruh wilayah masyarakat sehingga mudah diakses. Kemudahan akses juga dapat meningkatkan rasa kepercayaan masyarakat terhadap sistem bantuan hukum. Akses juga tidak hanya berkaitan dengan lokasi, tapi juga waktu. Perlu diketahui juga berapa waktu yang disediakan oleh lembaga bantuan hukum dalam sehari atau seminggu untuk memberikan layanan bantuan hukum.

Persoalan akses juga berkaitan dengan penyebaran informasi atau sosialiasi akan keberadaan lembaga bantuan hukum pada masyarakat. Jika masyarakat sudah tersosialisasikan dan mengetahui keberadaan lembaga bantuan hukum yang berada di wilayahnya maka hal tersebut ikut memperbesar akses bantuan hukum di masyarakat.

2. Kesederhanaan sistem untuk mengakses bantuan hukum (simplicity of the system for obtaining primary legal aid)
Sistem bantuan hukum juga sebaiknya dibuat sederhana atau diberikan panduan yang memudahkan. Sehingga sistem bantuan hukum itu mudah diakses oleh penerima bantuan hukum dan mudah dilakukan oleh pemberi bantuan hukum.

3. Kecepatanrespon bantuanhukum(Speediness in the provision of such aid)

Seberapa cepat lembaga bantuan hukum memberikan respon terhadap permintaan bantuan hukum juga menjadi tolak ukur keberhasilan sistem bantuan hukum. Respon yang cepat juga dapat meningkatkan kepercayaan masyarakat terkait sistem bantuan hukum yang berlangsung. Respon cepat juga berkaitan dengan berapa banyak tahapan yang perlu ditempuh pemohon bantuan hukum untuk mendapatkan layanan bantuan hukum.

\section{ANALISIS}

Berdasarkan pembahasan di atas, maka dapat diketahui bahwaakses terhadap program bantuan hukum bagi masyarakat miskin masih terbatas terutama karena minimnya keberadaan organisasi pemberi bantuan hukum. Oleh karena itu, perlu dilakukan rencana aksi berupa kebijakan, sebagai berikut:

\section{Kelembagaan}

Hasil FGD di Provinsi Aceh terungkap bahwa secara umum terkait hubungan antar kelembagaan tidak muncul banyak perubahan. Hal ini diakibatkan oleh minimnya pemahaman dan pengetahuan dari Aparat Penegak Hukum (APH) terhadap materi dan isi Undang-Undang No. 16 Tahun 2011. Pengadilan dan kejaksaan secara jelas menginformasikan bahwa hubungan antara kelembagaan ditingkat criminal justice system yaitu polisi, jaksa dan pengadilan masih mengacu pada KUHAP. Sementara pemahaman pengadilan dan kejaksaan terhadap $\mathrm{OBH}$ penyedia bantuan hukum hanyalah Posbakum yang selama ini sudah menjalin kerjasama, berupa penunjukan untuk mendampingi tersangka dan terdakwa yang secara khusus ancaman hukumannya di atas lima tahun.

Polisi juga mengatakan belum mendapatkan sosialisasi tentang Undang-Undang Bantuan Hukum. Polisi pada umumnya belum mengetahui 
apa saja OBH terakreditasi yang ada dalam wilayah hukumnya. Namun, memang ada beberapa kantor kepolisian yang sudah menjalin kerjasama dengan OBH yang terakreditasi. Bentuk kerjasama adalah apabila ada tersangka yang membutuhkan bantuan hukum, maka polisi akan merekomendasikan $\mathrm{OBH}$ tersebut untuk memberikan bantuan hukum.

Hasil FGD di Provinsi Jawa Timur juga terungkap bahwa masih terdapat permasalahan terkait pemahaman peran masing-masing pihak antara aparat penegak hukum (APH) dengan organisasi bantuan hukum. Persepsi APH yang menganggap $\mathrm{OBH}$ menyulitkan proses pemeriksaan. Hal yang demikian juga terjadi di Provinsi Kalimantan Selatan, dimana terdapat perbedaan pandangan yang terjadi antara pihak pengadilan dan pihak kantor wilayah kementerian hukum dan HAM dalam hal keputusan hakim (Inkracht), dimana dalam hal pertanggungjawaban diperlukannya adanya petikan putusan hakim, sementara hakim menganggap bahwa dengan salinan saja sudah cukup.

Persoalan pemahaman APH berkaitan juga dengan akses. Pemahaman APH yang baik akan memperluas akses masyarakat miskin untuk mendapatkan bantuan hukum, sehingga diperlukan sosialisasi kepada APH dan masyarakat. Jika APH dan masyarakat sudah tersosialisasikan, maka mereka akan mengetahui keberadaan $\mathrm{OBH}$ yang berada di wilayahnya dengan demikian dapat memperbesar akses bantuan hukum di masyarakat.

Mengenai sosialisasi, prakteknya di Indonesia juga kurang maksimal. BPHN baru melakukan sosialisasi ke OBH terakreditasi di beberapa daerah di Indonesia. Belum ada sosialisasi ke masyarakat yang sifatnya menyeluruh. Sehingga masyarakat mengetahui jasa bantuan hukum berdasarkan informasi akan reputasi OBH tersebut yang memang sudah sejak lama memberikan bantuan hukum. Oleh karena itu, sosialisasi di setiap kelurahan perlu dilakukan guna memberikan informasi tentang keberadaan program bantuan hukum cuma-cuma dari Negara (Kementerian Hukum dan HAM).

\section{Akses dan Layanan Bantuan Hukum}

Berdasarkan Keputusan Menteri Hukum dan Hak Asasi Manusia Republik Indonesia Nomor: M.HH-01.HN.03.03 Tahun 2016 tentang Lembaga/Organisasi Bantuan Hukum Yang Lulus Verifikasi Dan Akreditasi Sebagai Pemberi
Bantuan Hukum Periode Tahun 2016 S.D. 2018, ada $405 \mathrm{OBH}$ yang lulus verifikasi dan mendapat nilai akreditasi. Dari jumlah tersebut, $12 \mathrm{OBH}$ mendapat akreditasi A, 60 OBH mendapat akreditasi B, dan $333 \mathrm{OBH}$ berakreditasi C. OBH yang berakreditasi A memiliki standar paling sedikit dalam satu tahun menangani 60 kasus litigasi, melakukan 7 program layanan bantuan hukum non-litigasi, memiliki 10 advokat dan 10 paralegal. Untuk OBH berakreditasi B dalam satu tahun paling sedikit menangani 30 kasus litigasi, melakukan 5 program bantuan hukum non-litigasi, memiliki 5 advokat dan 5 paralegal. Sementara itu, untuk $\mathrm{OBH}$ yang berakreditasi $\mathrm{C}$ memiliki standar paling sedikit dalam satu tahun menangani 10 kasus litigasi, melakukan 3 program bantuan hukum non litigasi, memiliki 1 orang advokat dan 3 paralegal.

Selanjutnya untuk bisa mempertahankan atau meningkatkan nilai akreditasi tersebut, OBH harus bisa memenuhi standar-standar di atas. Melihat jumlah penanganan kasus litigasi, jika $405 \mathrm{OBH}$ tersebut bisa memenuhi standar yang ditentukan maka dalam setahun bisa menangani paling sedikit 5.850 perkara dalam mekanisme bantuan hukum. Berdasarkan data dari Direktorat Jenderal Pemasyarakatan (Ditjen Pas), jumlah narapidana dan tahanan di seluruh Indonesia berjumlah 199.989 orang. Di antara jumlah tersebut, jumlah tahanan adalah 68.493 orang. Data tersebut berasal dari 33 provinsi di Indonesia yang diperoleh dari Sistem Database Pemasyarakatan (Smslap. ditjenpas.go.id) per tanggal 27 Juni 2016.

Jika membandingkan jumlah minimum penanganan perkara oleh $\mathrm{OBH}$ di seluruh Indonesia yang berjumlah 5.850 perkara dengan kebutuhan bantuan hukum di tahanan sejumlah 68.493 orang, maka akses layanan bantuan hukum masih cukup jauh dari harapan. Selain itu, OBH tidak hanya menangani kasus para tahanan tapi juga kasuskasus dari pengaduan umum sehari-hari. Selain jumlah, potensi akses layanan bantuan hukum ini juga memiliki persoalan dalam hal pemerataan. Dari 405 OBH di seluruh Indonesia, mayoritas berlokasi di Pulau Jawa yaitu sejumlah 199 OBH. Paling banyak berlokasi di Provinsi Jawa Timur yaitu sejumlah $44 \mathrm{OBH}$. Sementara itu, banyak daerah di luar Jawa yang belum terjangkau oleh $\mathrm{OBH}$ atau hanya memiliki $2 \mathrm{OBH}$ di wilayahnya yaitu Provinsi Bangka Belitung. Wilayah Provinsi Maluku hanya $5 \mathrm{OBH}$ dan Provinsi Papua yang luas saja hanya memiliki 4 OBH di wilayahnya 


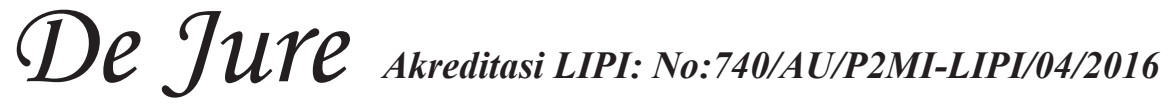

Hasil FGD di Provinsi Sumatera Selatan terungkap bahwa layanan bantuan hukum tentu harus bisa diakses oleh masyarakat yang membutuhkan. Lembaga pemberi bantuan hukum harus bisa menjangkau seluruh wilayah masyarakat sehingga mudah diakses. Kemudahan akses juga dapat meningkatkan rasa kepercayaan masyarakat terhadap sistem bantuan hukum. Akses juga tidak hanya berkaitan dengan lokasi, tapi juga waktu. Perlu diketahui juga berapa waktu yang disediakan oleh lembaga bantuan hukum dalam sehari atau seminggu untuk memberikan layanan bantuan hukum.

Di Indonesia, hasil verifikasi terhadap OBH menunjukkan bahwa jumlahnya di Indonesia belum merata. Sebagian besar masih berlokasi di pulau Jawa dan ada daerah-daerah yang belum terjangkau oleh $\mathrm{OBH}$ yang lulus verifikasi. Guna mengatasi kendala yang ada, maka diperlukan: $\mathrm{OBH}$ yang telah terakreditasi dapat menempatkan advokatnya di kabupaten/kota yang belum ada OBH guna memperluas akses bantuan hukum bagi masyarakat miskin dan juga dapat meminimalisir biaya transportasi. Kemudian, diperlukan kebijakan teknis dari Kementerian Hukum dan HAM terkait OBH yang tidak lolos verifikasi dan akreditasi dapat bekerjasama dengan OBH yang terakreditasi. Dalam hal ini advokat yang ada di $\mathrm{OBH}$ yang tidak terakreditasi dapat dipekerjakan pada OBH terakreditasi.

Selanjutnya, pemerintah dapat mengusulkan kepada organisasi Advokat untuk mendorong anggotanya yang berada di daerah agar dapat memberikan bantuan hukum secara cuma-cuma.

\section{Persyaratan dan Anggaran}

Bagi semua OBH yang terakreditasi, untuk bisa menyerap dan menggunakan anggaran bantuan hukum yang dialokasikan untuk mereka perlu terlebih dahulu menyediakan dan mengajukan berkas-berkas yang menjadi persyaratan administrasi pengajuan dana bantuan hukum. Sistem pendanaan yang digunakan adalah sistem reimbursement yang artinya penyaluran dana bantuan hukum baru diberikan setelah kegiatan bantuan hukum dilakukan dan $\mathrm{OBH}$ melaporkannya disertai dengan berkas-berkas pendukung. Apa yang dimaksud dengan berkas pendukung pada bantuan hukum litigasi adalah berkas-berkas yang digunakan dan terkait dengan penanganan perkara seperti surat kuasa, eksepsi, pembelaan, dan putusan. Sedangkan pada bantuan hukum non-litigasi, berkas-berkas pendukung disesuaikan dengan jenis kegiatan non-litigasi yang diajukan, misalnya daftar kepanitiaan acara penyuluhan hukum, dan laporan hasil investigasi hukum.

Berkaitan dengan persyaratan administrasi terungkap pada saat dilakukannya FGD di Provinsi Aceh yang menyatakan "Persyaratan akreditasi salah satunya adalah pernah menangani perkara sebanyak minimal 10 kasus. Banyak OBH yang memberikan bantuan hukum belum punya sampai dengan 10 kasus, sehingga mereka tidak dapat masuk dalam akreditasi BPHN. Inilah mungkin yang menjadi kendala, kenapa jumlah $\mathrm{OBH}$ yang telah terakreditasi sangat minim. Harapan kami, kedepan mungkin dapat diturunkan atau dihilangkan syarat tersebut, sehingga $\mathrm{OBH}$ yang belum menangani perkara dapat ikut berpartisipasi dalam bantuan hukum. Kebanyakan $\mathrm{OBH}$ yang gugur (tidak terakreditasi) sebenarnya memiliki advokat dan telah berbadan hukum".

Begitupun dengan syarat memiliki advokat yang terdaftar pada lembaga bantuan hukum atau organisasi. Syarat ini dipandang baik, namun dalam rangka memperluas akses bantuan hukum kepada masyarakat miskin, ada gagasan dimana bagi OBH (memiliki advokat) yang tidak masuk dalam akreditasi dapat bergabung dengan $\mathrm{OBH}$ yang telah terakreditasi. Dengan demikian, diharapkan advokat tersebut dapat ditempatkan pada kabupaten/kota yang belum ada $\mathrm{OBH}$.

Berdasar Undang-Undang Nomor 16 Tahun 2011 tentang Bantuan Hukum,pemberi bantuan hukum adalah lembaga bantuan hukum atau organisasi kemasyarakatan yang memberi layanan bantuan hukum berdasarkan Undang-Undang Bantuan Hukum. Untuk itu setiap pemberi bantuan hukum harus memenuhi syarat sebagaimana diatur dalam Pasal 17 sebagai berikut:

a) Berbadan hukum;

b) Terakreditasi berdasarkan Undang-Undang Bantuan Hukum;

c) Memiliki kantor atau sekretariat yang tetap;

d) Memiliki pengurus; dan

e) Memiliki program bantuan hukum.

Sementara itu, untuk melaksanakan ketentuan Pasal 7 ayat (1) huruf b yaitu syarat terakreditasi, Menteri berwenang: melakukan verifikasi dan akreditasi terhadap lembaga bantuan hukum atau organisasi kemasyarakatan 
untuk memenuhi kelayakan sebagai pemberi bantuan hukum berdasarkan undang-undang ini. Untuk itu ditetapkan Peraturan Menteri Hukum dan Hak Asasi Manusia Republik Indonesia Nomor 3 Tahun 2013 tentang Tata Cara Verifikasi dan Akreditasi Lembaga Bantuan Hukum Atau Organisasi Kemasyarakatan. Pasal 12 Peraturan Menteri Hukum dan Hak Asasi Manusia Republik Indonesia Nomor 3 Tahun 2013 menetapkan bahwa:

Lembaga bantuan hukum atau organisasi yang mengajukan permohonan verifikasi dan akreditasi sebagai pemberi bantuan hukum selain memenuhi syarat yang ditetapkan undang-undang juga harus memenuhi syarat: memiliki advokat yang terdaftar pada lembaga bantuan hukum atau organisasi dan telah menangani paling sedikit 10 (sepuluh) kasus.

Kedua syarat ini menjadi kesulitan organisasi pemberi bantuan hukum untuk dipenuhi. Dua syarat ini juga bila dicermati lebih jauh bertentangan dengan semangat program bantuan hukum bagi masyarakat miskin yang terkandung dalam UndangUndang Nomor 16 Tahun 2011 tentang Bantuan Hukum. Tidak terpenuhinya kedua syarat tambahan ini maka $\mathrm{OBH}$ semakin sedikit. Jumlah OBH yang sedikit akan sulit memberikan bantuan hukum kepada masyarakat miskin teristimewa di kabupaten/ kota yang jauh letaknya dengan ibukota provinsi. Dari analisis singkat ini, terbukti bahwa jumlah $\mathrm{OBH}$ sedikit maka semakin sulit masyarakat miskin memperoleh akses bantuan hukum.

Hasil FGD di Provinsi Aceh mengungkapkan bahwa sistem bantuan hukum juga sebaiknya dibuat sederhana atau diberikan panduan yang memudahkan. Sehingga sistem bantuan hukum itu mudah diakses oleh penerima bantuan hukum dan mudah dilakukan oleh pemberi bantuan hukum. Program bantuan hukum sudah berjalan sejak pertengahan tahun 2013, dan sudah banyak kemajuan dalam hal penyelenggaraan bantuan hukum. Dengan adanya Sidbakum yang dikembangkan oleh BPHN dirasakan sangat membantu dalam informasi maupun proses pelaporan, namun sistem ini dinilai masih lambat sehingga terjadi perbedaan dalam pelaporan sesungguhnya. Sistem Informasi Database Bantuan Hukum (Sidbakum) dinilai sudah baik namun perlu adanya pelatihan bagi operator pada $\mathrm{OBH}$. Sistem ini juga memiliki kelemahan, dimana jika $\mathrm{OBH}$ sudah mengupload dan terjadi kesalahan maka tidak dapat dihapus/diperbaiki. Hal ini perlu adanya hubungan yang baik antara $\mathrm{OBH}$ dengan BPHN langsung.

Seberapa cepat lembaga bantuan hukum memberikan respon terhadap permintaan bantuan hukum juga menjadi tolok ukur keberhasilan sistem bantuan hukum. Respon yang cepat juga dapat meningkatkan kepercayaan masyarakat terkait sistem bantuan hukum yang berlangsung. Respon cepat juga berkaitan dengan berapa banyak tahapan yang perlu ditempuh pemohon bantuan hukum untuk mendapatkan layanan bantuan hukum.

Di Indonesia, tahapan pengajuan permohonan bantuan hukum memang tidak berbelit-belit. Pemohon bantuan hukum cukup datang langsungke kantor pemberi bantuan hukum untuk mengajukan permohonan tersebut. Kendalanya justru terletak pada persyaratan Surat Keterangan Tidak Mampu (SKTM) bagi calon penerima bantuan hukum. Pembuatan SKTM bagi calon penerima bantuan hukum justru dapat memperlambat respon dari $\mathrm{OBH}$, sebab ada beberapa $\mathrm{OBH}$ yang baru memberikan pelayanan bantuan hukum apabila pemohon bantuan hukum sudah memiliki SKTM.

Di dalam peraturan pelaksanan UndangUndang Bantuan Hukum, pemerintah memang memberikan sedikit kelonggaran terkait SKTM. Sebagai ganti SKTM, penerima bantuan hukum juga bisa menggunakan Kartu Raskin, Kartu Jamkesmas, Kartu Bantuan Langsung Tunai, atau dokumen lain. Selain itu, ada juga ketentuan mengenai kewajiban kepada lurah/kepala desa/ pejabat setingkat untuk mengeluarkan SKTM atau dokumen lain untuk keperluan penerimaan bantuan hukum. Bahkan dengan adanya Peraturan Menteri Hukum dan Hak Asasi Manusia Republik Indonesia Nomor 10 Tahun 2015 tentang Peraturan Pelaksanaan Peraturan Pemerintah Nomor 42 Tahun 2013 tentang Syarat dan Tata Cara Pemberian Bantuan Hukum dan Penyaluran Dana Bantuan Hukum Pasal 34 ayat (3) terkait dokumen SKTM dapat digantikan dengan surat keterangan dari Kepala Kepolisian atau Kepala Kejaksaan Negeri atau Kepala Rutan atau Kepala 


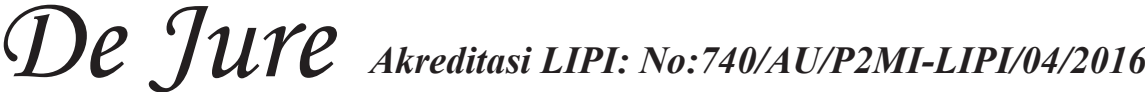

Lembaga Pemasyarakatan atau Ketua Pengadilan Negeri atau Ketua Majelis Hakim yang memeriksa perkara orang miskin.

Meski ada ketentuan tersebut, pengurusan pembuatan SKTM sering mendapat kesulitan. Hal ini diperkuat dengan hasil FGD yang mengungkapkan bahwa dalam menjalankan program non-litigasi (konsultasi hukum) yang pembiayaannya sebesar Rp. 700.000 diperlukan juga SKTM. Sedangkan untuk memperoleh SKTM tersebut perlu mengeluarkan biaya yang jumlahnya tidak sedikit.

Menurut $\mathrm{OBH}$ yang menjadi narasumber dalam FGD, anggaran bantuan hukum yang kurang mencukupi juga menjadi salah satu permasalahan. Pada penanganan satu perkara litigasi, standar besaran biaya yang diberikan Kementerian Hukum dan HAM adalah lima juta rupiah (Rp 5.000.000). Sementara itu, besaran biaya bantuan hukum nonlitigasi berbeda-beda tergantung jenis kegiatannya. Alokasi anggaran non-litigasi terbesar ada pada kegiatan penyuluhan hukum, yaitu sebesar Rp 3.740.000.

Bagi sebagian besar OBH, dana Rp 5.000.000 untuk satu perkara litigasi dianggap kurang mencukupi. Apalagi ketika menangani kasus perdata, dimana perkara perdata dalam prakteknya membutuhkan biaya yang cukup besar. Biaya yang dimaksud adalah untuk biaya pendaftaran perkara, pendaftaran surat kuasa, biaya menghadirkan saksi, dan lain-lain. Hal ini terungkap pada diskusi yang menyebutkan bahwa pendanaan dirasakan sangat minim terutama penanganan kasus perdata. Anggaran sebesar Rp 5.000.000 dikhawatirkan tidak mencukupi. Anggaran tersebut juga dipastikan tidak mencukupi pada provinsi-provinsi dengan kondisi geografis kepulauan.

\section{KESIMPULAN}

Bantuan hukum menjadi salah satu upaya untuk mendorong pelaksanaan hak-hak warga negara dalam menjalani proses hukum. Bantuan hukum juga berpeluang dapat mencegah terjadinya pelanggaran terhadap hak-hak hukum individu yang sudah diatur dalam peraturan perundangundangan maupun instrumen hukum internasional. Pengaturan bantuan hukum dalam undang-undang tersendiri merupakan salah satu bentuk penegasan terhadap hak masyarakat atas bantuan hukum dan pengaturan lebih lanjut jaminan hak konstitusional warga negara yang telah diatur dalam UndangUndang Dasar Negara Republik Indonesia Tahun 1945.

Keberadaan progam bantuan hukum yang merupakan implementasi Undang-Undang Bantuan Hukum belum sepenuhnya dipahami oleh aparat penegak hukum. Sistem bantuan hukum yang dijalankan oleh aparat penegak hukum masih mengacu pada ketentuan peraturan perundangundangan yang lama.

Minimnya pemahaman terhadap aturan bantuan hukum yang baru ini juga berimplikasi pada persoalan koordinasi dalam pelayanan bantuan hukum selama proses hukum dijalankan. Kondisi ini, di satu sisi menunjukkan bahwa respon terhadap sistem bantuan hukum lebih banyak berasal dari organisasi pemberi bantuan hukum dibandingkan dengan aparat penegak hukum. Di sisi lain, beberapa lembaga juga belum menyesuaikan program bantuan hukumnya dengan ketentuan Undang-Undang Bantuan Hukum.

Akses terhadap program bantuan hukum bagi masyarakat masih terbatas terutama karena minimnya keberadaan organisasi pemberi bantuan hukum atau akses wilayah yang sulit dicapai secara geografis. Pengembangan layanan bantuan hukum merupakan inisiatif dari pemerintah pusat yang harus direspon oleh Kementerian Hukum dan HAM dengan mengefektifkan pemberian layanan bantuan hukum dan memperluas akses masyarakat untuk mendapatkan bantuan hukum.

Pada tataran dukungan dana bagi organisasi bantuan hukum juga menyimpan persoalan bagi efektivitas pelaksanaan bantuan hukum dimana perbandingan dukungan dana dengan kebutuhan dalam pemberian bantuan hukum yang tidak sebanding. Selain ketidakcukupan dalam memenuhi kebutuhan pemberian bantuan hukum, pendanaan ini juga tidak dapat memberikan jaminan keberlanjutan organisasi pemberi bantuan hukum.

\section{SARAN}

Dalam rangka memperluas akses bantuan hukum bagi masyarakat miskin, maka BPHN perlu merevisi Peraturan Menteri Hukum dan Hak Asasi Manusia Republik Indonesia Nomor 3 Tahun 2013 tentang Tata Cara Verifikasi Dan Akreditasi Lembaga Bantuan Hukum Atau Organisasi Kemasyarakatan khusus Pasal 12 huruf 


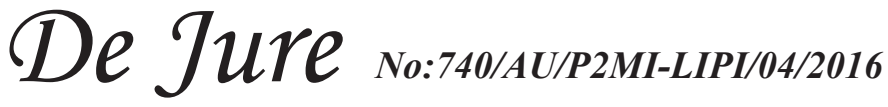

e "Memiliki advokat yang terdaftar pada lembaga bantuan hukum atau Organisasi" dan huruff "Telah menangani paling sedikit 10 (sepuluh) kasus".

Dalam upaya meningkatkan kualitas pemberian bantuan hukum bagi masyarakat miskin, maka Kementerian Hukum dan HAM R.I perlu meninjau kembali penerapan besaran dana bantuan hukum dengan mempertimbangkan besaran dana secara proporsional sesuai dengan kondisi/kebutuhan masing-masing daerah.

Kementerian Hukum dan HAM R.I perlu meningkatan koordinasi melalui forum DILKUMJAKPOL (Pengadilan, Kantor Wilayah Kementerian Hukum dan HAM Kejaksaaan, dan Kepolisian) dalam menyelaraskan pemahaman tentang implementasi bantuan hukum dan perlu memperluas jangkauan sosialisasi hinggake tingkat desa/kelurahan guna meningkatkan pemahaman kepada aparat penegak hukum dan masyarakat pada umumnya tentang program bantuan hukum bagi masyarakat miskin.

Dalam hal dukungan data terhadap tahanan miskin, maka Direktorat Jenderal Pemasyarakatan perlu melakukan pendataan tahanan miskin agar data tersebut dapat digunakan secara langsung oleh BPHN sebagai penyelenggara bantuan hukum maupun lembaga bantuan hukum atau organisasi kemasyarakatan sebagai pemberi bantuan hukum. 


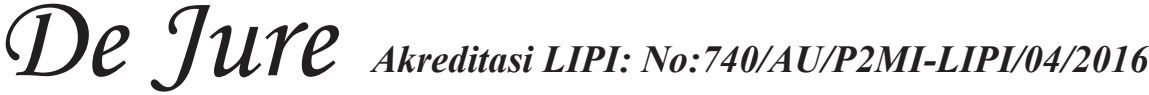

\section{DAFTAR KEPUSTAKAAN}

Andan Adi Satriawan, Upik Hamidah SH. MH dan Satria Prayoga SH. MH., Implementasi Bantuan Hukum Pada Masyarakat Miskin Di Kota Bandar Lampung (Studi Di Lembaga Bantuan Hukum Bandar Lampung), Bandar Lampung: Universitas Lampung, 2014

Asshiddiqie, Jimly, Hak Konstitusional Perempuan dan Tantangan Penegakannya, disampaikan pada acara Dialog Publik dan Konsultasi Nasional Komnas Perempuan "Perempuan dan Konstitusi di Era Otonomi Daerah: Tantangan dan Penyikapan Bersama", Jakarta, 27 November 2007

Badan Penelitian dan Pengembangan Hak Asasi Manusia, Peran Pemerintah Daerah Dalam Pemenuhan Hak Atas Keadilan, Jakarta: Pohon Cahaya, 2012

Badan Penelitian dan Pengembangan Hak Asasi Manusia, Hak atas Layanan Bantuan Hukum Bagi Masyarakat Miskin, Jakarta: Pohon Cahaya, 2015

Chrisbiantoro dan Wirataru, M Nur Sholikin Satrio, Bantuan Hukum Masih Sulit Diakses: Hasil Pemantau di Lima Provinsi Terkait Pelaksanaan Undang-Undang Nomor 16 Tahun 2011 tentang Bantuan Hukum, Jakarta: Kontras dan PSHK, 2014

Ibrani, Julius. Ed. Bantuan Hukum: Bukan Hak yang Diberi. Jakarta: YLBHI, 2013

Irwanto, Focus Group Discussion: Sebuah Pengantar Praktis. Jakarta: Yayasan Obor Indonesia, 2006

Lembaran Baru Bantuan Hukum Bagi si Miskin, Berita LBH Jakarta. Edisi SeptemberNovember 2013

Sudaryono, Pemenuhan Hak Atas BAntuan Hukum Dalam Proses Peradilan Pidana To Promote: Membaca Perkembangan Wacana Hak Asasi Manusia di Indonesia, Yogyakarta: PUSHAM UII, 2012

UNDP, International Study of Primary Legal Aid Systems with the Focus on the Countries of Central and Eastern Europe and CIS, 2012.
Winarta, Frans H, Bantuan Hukum Bagi Semua Warga Negara, Jakarta: PT. Elex Media Komputindo, 2011

\section{Peraturan Perundang-Undangan}

Undang-Undang Dasar Negara Republik Indonesia Tahun 1945.

Undang-Undang Republik Indonesia Nomor 39 Tahun 1999 tentang Hak Asasi Manusia.

Undang-Undang Republik Indonesia Nomor 16 Tahun 2011 tentang Bantuan Hukum.

Peraturan Pemerintah Republik Indonesia Nomor 42 Tahun 2013 tentang Syarat dan Tata Cara Pemberian Bantuan Hukum dan Penyaluran Dana Bantuan Hukum.

Peraturan Menteri Hukum dan Hak Asasi Manusia Republik Indonesia Nomor 3 Tahun 2013 tentang Tata Cara Verifikasi dan Akreditasi Lembaga Bantuan Hukum Atau Organisasi Kemasyarakatan.

Peraturan Menteri Hukum dan Hak Asasi Manusia Republik Indonesia Nomor 10 Tahun 2015 tentang Peraturan Pelaksanaan Peraturan Pemerintah Nomor 42 Tahun 2013 tentang Syarat dan Tata Cara Pemberian Bantuan Hukum dan Penyaluran Dana Bantuan Hukum.

Keputusan Menteri Hukum dan Hak Asasi Manusia Republik Indonesia Nomor: M.HH01.HN.03.03 Tahun 2016 Tentang Lembaga/ Organisasi Bantuan Hukum Yang Lulus Verifikasi Dan Akreditasi Sebagai Pemberi Bantuan Hukum Periode Tahun 2016 S.D. 2018.

\section{Sumber Lain}

Smslap.ditjenpas.go.id 


\section{De JuYe akreditasi LIPI: No:740/AU/P2MI-LIPI/04/2016}

\section{BIODATA PENULIS}

Nama, Oki Wahju Budijanto, S.E., M.M., Lahir di Jakarta tanggal 27 Oktober 1976. Bekerja di Kementerian Hukum dan HAM Republik Indonesia sebagai Fungsional Peneliti Muda Bidang Studi Hukum dan Hak Asasi Manusia merangkap Kepala Sub Bidang Meta Analisis Data Penelitian Hukum pada Pusat Pengembangan Data dan Informasi Penelitian Hukum dan Hak Asasi Manusia. Menamatkan pendidikan S1 di Fakultas Ekonomi Universitas Trisakti (selesai tahun 2001), kemudian melanjutkan pendidikan S2 pada Pasca Sarjana Universitas Bhayangkara Jakarta Raya (selesai tahun 2007). Telah Mengikuti Pendidikan dan Pelatihan Fungsional Peneliti Tingkat Pertama LIPI (2003), Pendidikan dan Pelatihan Metodologi Penelitian LIPI (2004) serta Pendidikan dan Pelatihan Fungsional Peneliti Tingkat Lanjutan LIPI (2016). Pendidikan dan Pelatihan Struktural : Diklat Kepemimpinan Tk. IV ( 2009) dan Diklat Kepemimpinan Tk. III (2013). Disamping itu, pernah mengikuti Human Rights Training for Indonesia Agencies di New Zealand (2007). Pengalaman menjadi Narasumber pada acara sosialisasi di beberapa daerah : Kabupaten Jember dan Kabupaten Semarang (terkait dengan Evaluasi Efektivitas Forum Pengadilan, Hukum dan HAM, Kejaksaan dan Kepolisian Dalam Kerangka Integrated Criminal Justice System) serta Kabupaten Tarutung, Kabupaten Lebak, Kabupaten Klungkung (terkait dengan Evaluasi Peran Pemerintah Daerah Dalam Pemenuhan Hak Atas Keadilan Terkait Akses Bantuan Hukum Bagi Masyarakat Miskin). 


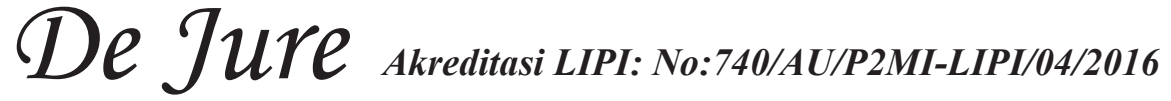

\section{PEDOMAN PENULISAN NASKAH JURNAL PENELITIAN HUKUM DE JURE}

1. Naskah yang dimuat dalam Jurnal Penelitian Hukum De Jure adalah tulisan yang belum pernah dipublikasikan dalam media massa.

2. Naskah yang dimuat dalam Jurnal Penelitian Hukum De Jure meliputi tulisan tentang hasil penelitian (penelitian empiris maupun penelitian normatif atau studi dokumenter), pemikiran dan informasi lain yang bersifat ilmiah.

3. Menggunakan bahasa Indonesia yang baku.

4. Sistimatika Penulisan :

A. Naskah artikel hasil penelitian empiris :

o Judul aktual

Menggambarkan isi naskah dan maksimal 14 kata ditulis dalam bahasa Indonesia dan Inggris

o Nama penulis

Tanpa gelar akademik, jabatan, kepangkatan, alamat lembaga/instansi dan e-mail

o Abstrak

Berisi Latar Belakang, Rumusan Masalah, Tujuan, Kegunaan, Metode, Isi

Pembahasan, Analisis, Kesimpulan dan Saran Temuan ditulis dalam satu spasi;

150 kata (10-20 baris/ satu (1) paragraf) diketik menggunakan huruf Times New

Roman; font 11 italic; ditulis dalam bahasa Indonesia dan bahasa Inggris.

o Kata Kunci

Mengandung yang di indekskan ditulis dalam bahasa Indonesia dan Inggris

dengan minimal 3 kata maksimal 5 kata

- PENDAHULUAN

Berisi latar belakang masalah dan rumusan masalah, tujuan, kegunaan, kerangka Teori/Konsep, Metode (metode penelitian yang digunakan, di antaranya meliputi jenis penelitian, lokasi penelitian, sumber data, teknik pengumpulan data, pengolahan data dan analisis data.)

- PEMBAHASAN

Berisi, pembahasan terhadap masalah yang diteliti

- Analisis

Berisi analisis dari semua pokok pembahasan

- PENUTUP

Kesimpulan dan saran

Kesimpulan dan saran ditulis dalam bentuk uraian bukan dalam bentuk'angka

- DAFTAR KEPUSTAKAAN

Daftar Pustaka : ditulis berdasarkan abjad, dengan urutan : Nama pengarang. Judul buku. Kota penerbit: nama penerbit, tahun penerbitan.

Contoh ....Hamzah. Andi, Bantuan Hukum suatu Tinjauan Yuridis. Ghalia

Indonesia, Jakarta, 1983. 


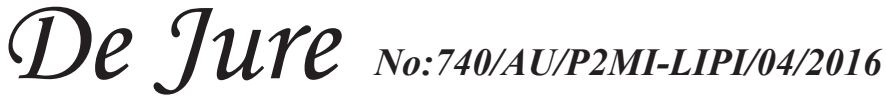

B. Naskah artikel ulasan Hasil penelitian normatif atau studi dokumenter), pemikiran dan informasi lain yang bersifat ilmiah.

o Judul aktual

Menggambarkan isi naskah dan maksimal 14 kata ditulis dalam bahasa

Indonesia dan Inggris

o Nama penulis

Tanpa gelar akademik, jabatan, kepangkatan, alamat lembaga/instansi dan e-mail

o Abstrak

Berisi Latar Belakang, Rumusan Masalah, Tujuan, Kegunaan, Metode, Isi

Pembahasan, Analisis, Kesimpulan dan Saran Temuan ditulis dalam satu spasi;

150 kata (10-30 baris/ satu (1) paragraf) diketik menggunakan huruf Times

New Roman; font 11 italic; ditulis dalam bahasa Indonesia dan bahasa Inggris

o Kata Kunci

Mengandung yang di indekskan ditulis dalam bahasa Indonesia dan Inggris

minimal 3 kata maksimal 5 kata

- PENDAHULUAN

Latar belakang masalah dan rumusan masalah

- PEMBAHASAN

Berisi, pembahasan terhadap masalah yang dikaji

- ANALISIS

Berisi analisis dari semua pokok pembahasan

- PENUTUP

Kesimpulan Dan Saran

Kesimpulan dan saran ditulis dalam bentuk uraian bukan dalam bentuk angka

- DAFTAR KEPUSTAKAAN

Daftar Pustaka : ditulis berdasarkan abjad, dengan urutan : Nama pengarang. Judul buku. Kota penerbit : nama penerbit, tahun penerbitan.

Contoh ....Hamzah. Andi, Bantuan Hukum suatu Tinjauan Yuridis. Ghalia

Indonesia, Jakarta, 1983.

5. Naskah dilengkapi dengan indeks.

6. Naskah diketik rapi 1,5 spasi di atas kertas A4; menggunakan huruf Times New Roman; Font 11; antara 20-30 halaman; diprint out dan disertai soft copy CD.

7. Penulisan kutipan sumber rujukan dengan sistem bodynote, yaitu menulisk ${ }^{\wedge} \mathrm{n}$ nama pengarang (tanpa gelar akademik); tahun penerbitan dan no halaman, yang ditulis dalam kurung; diletakan dibelakang kutipan. Contoh : .(Hamzah, 2007: 15)

8. Isi tulisan di luar tanggungjawab redaksi. Dan redaksi berhak mengedit redaksional tanpa merubah arti.

9. Naskah yang belum memenuhi syarat akan dikonfirmasikan atau dikembalikan untuk diperbaiki.

10. Keterangan lengkap dapat menghubungi redaksi Jurnal Peneltian Hukum De Jure melalui Email: jurnaldejure@yahoo.com 